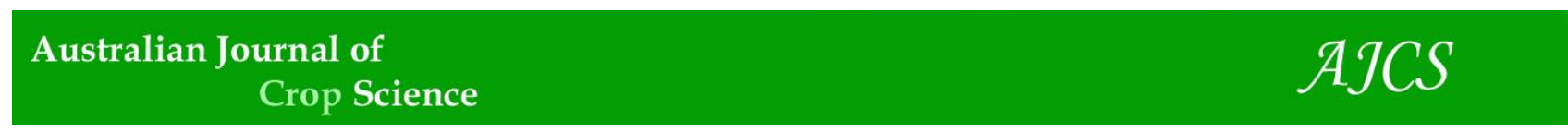

AJCS 14(01):7-12 (2020)

ISSN:1835-2707

doi: 10.21475/ajcs.20.14.01.p1359

\title{
Recovery and seeds germination of four important tropical forage legumes in bovine dung
}

\author{
Bruno Borges Deminicis ${ }^{1 *}$, Henrique Duarte Vieira ${ }^{2}$, João Carlos de Carvalho Almeida ${ }^{3}$, Tiago Neves \\ Pereira Valente ${ }^{4}$, Saulo Alberto do Carmo Araújo ${ }^{5}$, Renata Vianna Lima ${ }^{6}$
}

${ }^{1}$ Universidade Federal do Sul da Bahia, Teixeira de Freitas, BA 45990-000 Brazil

2Universidade Estadual do Norte Fluminense Darcy Ribeiro, Campos dos Goytacazes, RJ 28013-600 Brazil

${ }^{3}$ Universidade Federal Rural do Rio de Janeiro, Seropédica, RJ 23890-000 Brazil

${ }^{4}$ Instituto Federal Goiano, Posse Campus, GO 73900-000, Brazil.

${ }^{5}$ Universidade Federal dos Vales do Jequitinhonha e Mucuri, Unaí, MG 38610-000 Brazil

${ }^{6}$ Instituto Federal de Educação, Ciência e Tecnologia do Espírito Santo, Colatina, ES 9709-800 Brazil

\section{*Corresponding author: brunodeminicis@gmail.com}

\section{Abstract}

This experiment was conducted to evaluate the recovery and survival of tropical forage legume seeds (butterfly pea, stylosanthes, perennial soybean and macrotiloma) subjected through the digestive tract of cattle and to evaluate the germination of the seeds in feces of cattle. A $50 \mathrm{~g}$ of seed mixed with $150 \mathrm{~g}$ of mineral supplement offered to the cattle. Each cattle was considered as repetition. The bovine feces collected up to 60 hours after eating the seeds, where the seeds separated by sieves, using water, gloves procedure and tweezers. Later, they counted and divided into intact and swollen. For the germination test of the recovered seeds, 75 seeds per replicate were used ( 25 in natura, 25 intact and 25 swollen seeds, respectively). For the germination test in fecal plates, the bovine feces collected between 12 and 30 hours after eating the seeds. After 120 days, we evaluated the total amount of plants emerged within the study period (between 12 and 30 hours) and the average number of emerged plants per fecal signs. The results showed that cattle are facilitating the dispersion of butterfly pea, macrotyloma and perennial soybean, but not stylosanthes. The highest survival as the average number of germinated plants in fecal plates achieved by macrotyloma, followed by butterfly pea species and perennial soybean. The cattle were efficient in the pasture colonization process, due to the considerable dispersion of the seeds. This dispersion was not observed for seeds of stylosanthes.

Keywords: Cattle; dispersion; pastures; ruminant; seeds dormancy.

\section{Introduction}

The adoption of mixed pastures systems of forage grasses and legumes is an interesting alternative to increase animal productivity. This strategy aims to integrate the productivity of forage grass with high nutritional value and nitrogen fixation that forage legumes attach to system (Souza et al., 2002; Aroeira et al., 2005). One of the main obstacles in the adoption of mixed pastures of grasses and legumes, where the first is already established, is the cost of deploying these to the operating system.

In recent decades, researchers have found that the seed dispersal by herbivorous animals can influence the pasture colonization process, affecting the structure and composition of plant communities (Levine and Murrell, 2003; Pegado et al., 2006). Despite the classical view that the passage of seeds through the digestive tract of animals helps the germination process, some studies have pointed out that the effects of digestion on germination can vary considerably. The germination capacity may increase, decrease, or remain unchanged, compared with not-swallowed seeds (Figueroa and Castro, 2002; Lima et al., 2014). Seed properties such as the hardness of seed coat, seed size, shape and specific gravity are important to the survival of seeds passing through the digestive tract of livestock. Small-round seeds with smooth exteriors (Doucette et al., 2001), seeds with high specific gravity and impermeable seeds typically have high recovery and survival (Rahimi et al., 2006). Although the importance of natural reseeding for renewal and persistence of species in pastures have been sufficiently discussed, the role of cattle in this process is scarce (Blackshaw and Rode, 1991).

It is known that small seed of forage species remain viable after passing through the digestive tract of ruminants (Bray et al., 1998). The use of cattle as dispersal agents is an interesting technology in the long term. It guarantees the spread of plants over large areas. Once established, legumes tend to perpetuate themselves in space through time (Silva et al., 2007). Based on this information, this study aimed to evaluate the recovery of seeds of butterfly pea seeds (Clitorea ternatea), stylosanthes cv. Campo Grande (Stylosanthes capitata and Stylosanthes macrocephala), macrotyloma (Macrotyloma axillare) and perennial soybean (Neonotonia wightii). We also evaluated the influence of the 
digestive tract of cattle on seedling emergence and germination/survival of seeds by observing the presence of plants in bovine fecal plates.

\section{Results and Discussion}

The result of recovery and survival of seeds is shown in Table 1. The analysis of variance showed a significant effect $(P<0.05)$ of species to seeds that presented in the feces.

The regression analysis shows the equations that describe the behavior of the percentage of recovered and germinated seeds, after passage through the digestive tract of cattle (Figure 2). The results of seeds germination in fecal plates are shown in Figures 3 and 4.

The number of seeds recovered in the feces showed variation between animals, although these animals selected by breed, weight and age and managed in stalls. Lisboa et al., (2009), also observed these variations. A 28.5, 56.8, 30.3 and $2.1 \%$ of macrotyloma, butterfly pea, perennial soybean and stylosanthes ingested seeds (seed supplied to animals) were recovered in feces, respectively. The passage of whole seeds through the digestive tract of ruminants was observed in species of grasses and legumes, grown and native. Deminicis et al. (2009) found similar values. The results found that the total intact seed supplied to animals (ingested) were 14.0, $33.8,15.5$, and $0.08 \%$ of the seeds and $14.5 ; 23.0 ; 14.8$ and $2.0 \%$ were swollen in macrotyloma, Butterfly pea, perennial soybean and stylosanthes, respectively.

From the test, we observed germination of 49.5, 94.3, 50.5 and $36.0 \%$ of macrotyloma, Butterfly pea, perennial soybean and stylosanthes, respectively, disregarding some external factors such as attack of insects and animals to seeds. Considering the favorable germination conditions, we estimated that of $14.1,53.5,15.4$ and $0.8 \%$ of seed macrotyloma wedge, and perennial soybean stylosanthes, respectively, are ingested by the cattle but able to germinate in the feces.

Mouissie et al. (2005) studied the seed survival of 25 plant species introduced into the feed deer (Dame dama L.) and observed that 24 of the 25 species of plants ingested by animals survived and germinated in feces ( 0.5 to $42 \%$ of ingested seeds). In addition, $50 \%$ of all the seeds recovered in up to $25 \mathrm{~h}$.

Bråthen et al. (2007) studied the stocking (elk) of endozoochory, covering several ecological contexts and found effects of stocking on the spatial scale dispersion. They found that the highest densities of moose in the pasture provided greater abundance of feces and those containing few species emerging plants. In addition, no effect was observed on the level of grouping of excreta by higher density of animals. The botanical composition of the pasture considered an important ecological factor, because the most abundant species are the same, which have the largest number of emerged seedlings in the stool, thus dominating the pastures. The results of this study demonstrate that ruminants can neutralize the negative impact of grazing by the return of viable seeds in their droppings. Lima et al. (2014) evaluated the physiological quality of forage seeds after passage through the gastrointestinal tract of cattle, as well as the emergence of seedlings derived from these seeds, the tropical kudzu, leucaena and calopo. The best performance for the total number of seedlings in the feces of cattle was observed in the kudzu species. These authors also observed the length of the root, length of the aerial part and dry matter seedling weight in the leucaena species, followed by kudzu and the calopo, showing low results for all variables due to the high degradation of the seeds.

The response of perennial soybean ( 9.6 plants per plate) and stylosantes ( 3 plants per plate) were similar to that observed by Silva et al. (2007), similar to those evidenced in the Figure 3 and 4 . The total number of plants excreted in fecal plates was between 12 and 30 hours after ingestion. After 120 days, we found that macrotyloma species had an average of 64 plants, featuring improved performance compared to the other species under the conditions in this experiment.

The perennial soybean and wedge showed intermediate medium (both had 48 plants), whereas the low results obtained for stylosanthes species ( 3 plants per plate). These results mainly related to the dormancy breaking efficiency of seeds of each legume analyzed by passing through the digestive tract of cattle, in addition to the integument of the stamina and the embryo. However, other factors may have been decisive for the results, among which we can highligh the fermentation of feces, high contamination by fungi and bacteria, and the placement of the seeds in the stool, the thickness of the stool and surface dehydration of the stool. Bruun and Poschlod (2006), investigated the dispersion of endozoochory seeds through the digestive tract of cattle and plenty of samples in seed stool related to seed attributes. They found that a large proportion the ingested seeds was survived after passing through the digestive tract of cattle, producing the unit area on grazed vegetation. However, no effect was found between the potential of the dispersion (measured as the abundance of seeds in the samples of feces) and seed attributes such as seed mass, shape, and thickness of the seed coat. This shows the clear importance of the number of seeds produced per plant in the ability of dispersal of plant species. It also shows that grazing can be an important vector spreading too many species of plants conventionally classified as invasive.

Silva et al. (2007), also evaluated the germination of 5 ingested pulses seeds distributed in fecal plates the field. They reported that macrotyloma species averaged 13 plants per fecal plate, which was lower than those used in the study. Furthermore, in an established grazing, these authors observed competition for light, humidity and fertility between plants.

The performance of macrotyloma highlights the great superiority over other species, demonstrating its great potential when used in this dissemination method in grazing areas. However, these results should not give this plant the better condition for this purpose, since the percentage of germinated seeds with respect to the ingested seeds should be taken into account.

In this sense, for approximately 1,000 of intaken butterfly pea, 17,500 seeds of stylosanthes, 149,500 of perennial soybean and 5,000 of macrotyloma, we could estimate 1.27, $0.95,0.95$ to $0.06 \%$ of ingested seeds, respectively. The perennial soybean and stylosanthes could germinate in fecal plate until 120 days after excreted. Other fodder seeds may be in fecal plates awaiting a situation more suitable for germination. 
Table 1. Percentage of Intact seeds (I\%); Swollen (S\%); Digested (S\%); Germinated (G\%); Recovered in cattle dung and Germinated of macrotyloma, perennial soybean, butterfly pea and stylosanthes species.

\begin{tabular}{lccccc}
\hline Species & $\mathrm{I} \%$ & $\mathrm{~S} \%$ & $\mathrm{D} \%$ & $\mathrm{G} \%$ & $\mathrm{RG} \%$ \\
\hline macrotyloma & $14.00 \mathrm{Bb}$ & $14.50 \mathrm{Bb}$ & $71.5 \mathrm{Ab}$ & $49.50 \mathrm{~b}$ & $14.08 \mathrm{~b}$ \\
butterfly pea & $33.75 \mathrm{Aa}$ & $23.00 \mathrm{Ba}$ & $43.25 \mathrm{Aa}$ & $94.25 \mathrm{a}$ & $53.49 \mathrm{a}$ \\
perennial soybean & $15.50 \mathrm{Bb}$ & $14.75 \mathrm{Bb}$ & $69.75 \mathrm{Ab}$ & $50.75 \mathrm{~b}$ & $15.41 \mathrm{c}$ \\
stylosanthes & $0.075 \mathrm{Bc}$ & $2.00 \mathrm{Bc}$ & $97.92 \mathrm{Ac}$ & $36.00 \mathrm{c}$ & $0.75 \mathrm{C}$ \\
\hline CV \% & 12.62 & 18.53 & 5.24 & 5.85 & 11.79 \\
\hline *Means followed by the same capital letter in the row and column tiny and do not differ by Tukey test (5\%) & &
\end{tabular}

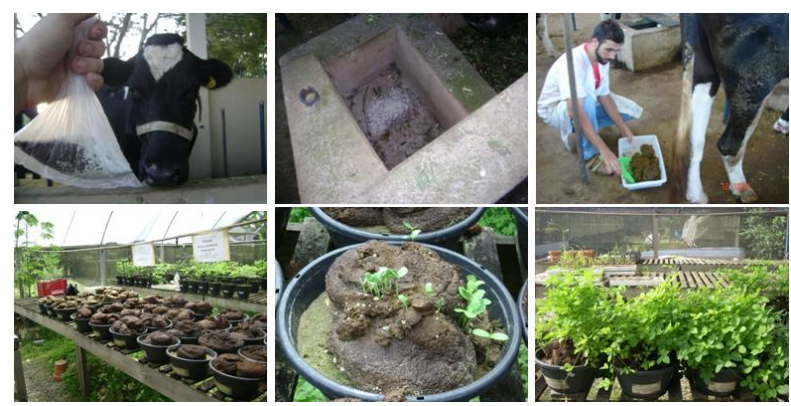

Fig 1. Offering seeds mixed with the mineral supplement to animal feces collection, placement of fecal plates in pots in the greenhouse and observation of the presence of plants germinated in bovine fecal plates.

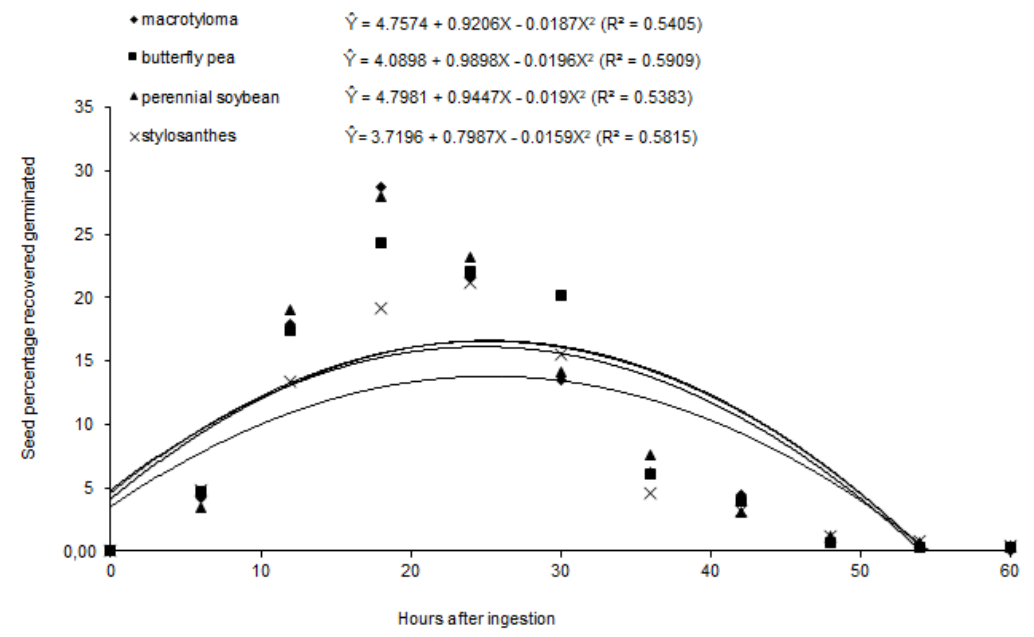

Fig 2. Regression for percentage seed recovered in bovine samples as a function of excretion period.

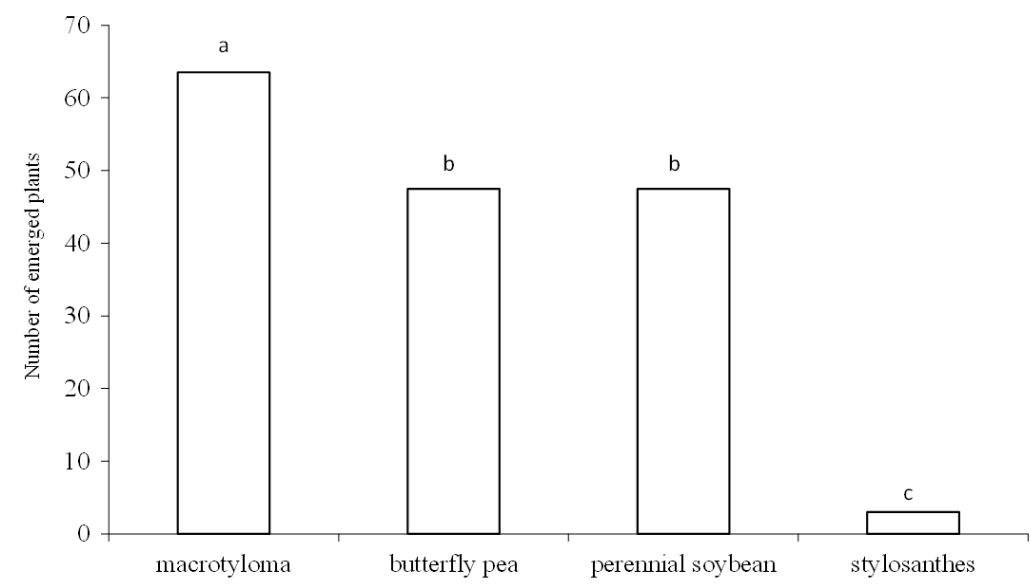

Fig 3. Total number of plants observed excreted in feces boards between 12 and 30 hours post-ingestion (*Lowercase same means that average in do not differ by Tukey test $p<0.05$ ). 


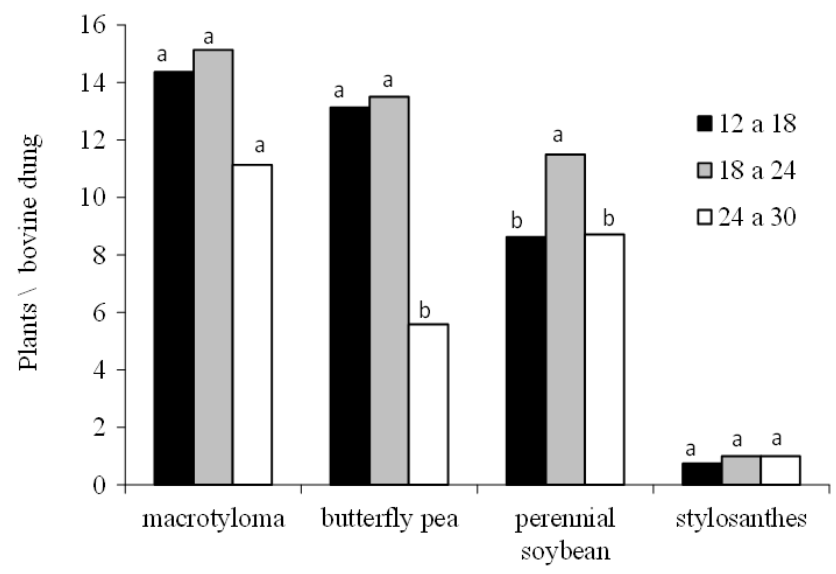

Fig 4. Average number of plant legumes by fecal plate due to the post-ingestion period, in which they excreted (24:18, 18:24, 00:30 hours), in a greenhouse. (* Lowercase same means that average in do not differ by Tukey test $p<0.05$ ).

Jones et al., (2001) evaluated the germination of several species for 11 years in the state of Queensland, Southeast Australia, collecting cow dung in 2 types of Setaria sphacelata pasture (intercropped with Macroptillium atropurpureum and not intercropped) under different stocking rates (high and low) in the spring, summer, autumn and winter. They observed that the percentage of germinated seeds in the feces is higher in summer-autumn than in winter-spring. Also, in summer-autumn the paddocks showed high stocking rates, which is probably effect of the amount and availability of seeds ingested by these animals during the rainy season. Jolaosho et al. (2006) found a rate of $5 \%$ germination of seeds dispersed by cattle during the rainy season (June to September) in Nigeria. These authors observed that seeds spread by goats and sheep have higher germination rate ( 32 and $28 \%$, respectively).

Peco et al. (2006) evaluated the importance of seed size, shape and coat impermeability in the endozoochorous dispersal process of 20 abundant species from central Iberian rangelands. These authors also evaluated the survival, germination percentages and germination speed in controlled experiments on the chewing and gut passage process by inserting seeds in the rumen of fistulated sheep, followed by simulated acid-pepsin digestion. These authors observed that species with impermeable seed coats had higher germination percentages following treatment, although no significant differences noted for either seed survival or germination speed. Gillet et al. (2010) investigated the plant community dynamics induced by dung deposition in two plant communities at $10-\mathrm{cm}$ and 1-month (a mesotrophic and an oligotrophic grassland) in a pasture of the Swiss Jura Mountains. They observed a lower grazing intensity near the dung pat for all observation periods. In the mesotrophic grassland, the canopy was higher near the dung pat already one week after dung deposition. They also observed a positive rank correlation between species turnover and distance to the dung for both communities, suggesting a seasonal stabilizing effect of dung on the plant composition of their direct surroundings $(0-10 \mathrm{~cm})$ likely due to cattle avoidance.

Deminicis et al. (2009) studied the effect of simulated chewing, fermentation and digestion enzyme acid in vitro on the survival of tropical forage legume seeds. They observed that the seeds, having hard and impermeable seed coats, kept high potential resistance, passing intact the digestive tract of cattle, being able to germinate when defecated in pastures. Deminicis et al. (2013) evaluated the survival rate of four tropical legume seeds (butterfly pea, stylosanthes, archer and perennial soybean) submitted to different periods of ruminal incubation simulated by in vitro and in situ fermentation. These authors observed that legume seeds presented high resistance potential when submitted to ruminal incubation due to their hard and impermeable teguments. Therefore, they have greater chances of germinating after passage through the gastrointestinal tract of bovines, when defecated in pastures. However, stylosanthes is not recommended for insertion in bovine feeding for this purpose, because they do not resist ruminal digestion. Lima et al. (2015) evaluated the germination and the vigor of three species of Fabaceae seeds submitted to 0 , $6,12,24,48,72$ and 96 hours of testing to natural (in situ incubation) and simulated conditions (in vitro incubation) from the ruminal environment of bovines. These authors verified higher percentages of normal plants for kudzu and leucaena kinds, when the seeds submitted to in situ incubation. Furthermore, they found that in vitro incubation revealed to be more harmful to the seeds of the three species used.

Nakao and Cardoso (2010) studied the influence of the ingestion of Leucaena leucocephalaseeds, Cajanus cajan and Calopogonium mucunoides by Bos taurus, on germination and viability, in order to evaluate the cattle as legitimate disperser of these species used as fodder. These authors found that eating the animals severely affected the germination of seeds of Cajanus cajan, while in Calopogonium mucunoides reduction of germination percentage was occurred on a smaller scale and the Leucaena germination was not affected by treatment. These authors suggest that cattle cannot considered legitimate seed dispersal. Almeida et al. (2015) studied the introduction of legumes in established Brachiaria decumbens pasture by dispersing in cattle feces. They found that all pulses are found in fecal plates. However, the percentage of germinated seeds in the feces compared to the quantity of seeds offered to animals (via feed) was low. However, they observed that cattle action could probably contribute to the reduction of 
reseeding costs leucena and calopo on small farms. Indirectly, the results highlight possible environmental impacts of the livestock invasion of biodiversity conservation areas, as they can act as disseminators potential agents of alien species. They stressed that there is still need for new experiments to understand the efficiency and effectiveness of seed dispersal of plant species by cattle under field conditions.

\section{Materials and Methods}

\section{Experimental site}

Two experiments were conducted in the Forage and Nutrition of Ruminants of Animal Laboratory and Animal Nutrition, belonging to the Centre of Agricultural Sciences and Technology of the Darcy Ribeiro North Fluminense State University (UENF) in Campos dos Goytacazes, RJ, Brazil. The first experiment sought to evaluate the seed recovery from cow dung and survival, and the second experiment sought to study the germination of seeds in fecal signs.

\section{Species of plants}

The species used butterfly pea seeds (Clitorea ternatea), stylosanthes Cv. Campo Grande (Stylosanthes capitata and Stylosanthes macrocephala), macrotyloma (Macrotyloma axillare) and perennial soybean (Neonotonia wightii).

\section{Treatments for laboratory tests}

To test recovery seeds in the cattle feces, $50 \mathrm{~g}$ of seeds fed to crossbred cattle (steers Holstein $x$ Zebu) with a live weight of $500 \mathrm{~kg}$, corresponding to approximately 1,000 seeds of Butterfly pea, 17,500 seeds of stylosanthe, and 149,500 perennial soybeans and 5,000 of macrotyloma, all in natura, whose humidity was around $22.7 \%, 12.3 \%, 25.9 \%, 27.8$, respectively. The seeds used in the study were recently harvested with viable germination capacity. The seeds offered at once, admixed with $150 \mathrm{~g}$ of mineral mixture to cattle during the morning feeding. The bovine tailings collected up to 60 hours after eating the seeds, precisely because this period not found over the presence of seeds in the feces. The animal feces were collected and transferred to the laboratory. The seeds separated through sieves, using water and gripper gloves. Then the seeds counted and divided into two classes: intact seeds (whose integument not affected in the ingestion and digestion) and swollen seeds.

For the germination test, they used 75 seeds per replicate (25 in natura, 25 intact and 25 swollen seeds). It is noteworthy that, as it is possible to remove seeds undigested stool for the count, the difference between the number of seeds ingested and the number of seeds found in the feces considered as the number of undigested seeds. Intact seeds and in natura scarified with sandpaper \# 100 grit, to be observed slots in husk of the seeds to break dormancy. After chiseling, the germination test was conducted, in which the seeds placed in germination chamber type BOD at $25^{\circ} \mathrm{C}$ with 12 hours of light. The swollen seeds not scarified, they put directly to germinate.

\section{Treatments for field tests and statistical procedures}

The experimental design was a completely randomized (CRD) with four replications (cattle). The recovery of seeds was determined after the excretion period. The parameters of normal plants in the germination test was ends 22 days after the date of sowing, and the results submitted to analysis of variance and mean test (Tukey $p<0.05$ ) for the comparison of means.

For the germination test of bovine fecal, we offered $50 \mathrm{~g}$ of Butterfly pea seeds (Clitorea ternatea) stylosanthes cv. Campo Grande (Stylosanthes capitata and Stylosanthes macrocephala), macrotyloma (Macrotyloma axillare) and perennial soybean (Neonotonia wightii) to crossbred cattle (Holstein x Zebu) with a live weight of $500 \mathrm{~kg}$, housed in individual pens. This corresponds to approximately 1,000 seed Butterfly pea, 17,500 seed stylosanthes, 149,500 of perennial soybean and 5,000 macrotyloma, all in natura, whose humidity at around 22.7, 12.3, 25.9 and 27.8\%, respectively. The seeds offered at once, admixed with $150 \mathrm{~g}$ of mineral mixture to cattle during the morning feeding. Cattle tailings fully collected between 12 and 30 hours after ingestion of the seeds (subdivided in 12-18, 18-24 and 24-30 hours). Feces collected taken in plastic bags to the greenhouse and arranged in a cylindrical vessel (height 15.0 $\mathrm{cm}, 32.0 \mathrm{~cm}$ top diameter, bottom diameter of $18.0 \mathrm{~cm}$ and volume $7.0 \mathrm{l}$ ) with plate (height $2.0 \mathrm{~cm}$, diameter $21.0 \mathrm{~cm}$ ) filled with washed sand, with the goal of reproducing degraded soil field conditions, where they remained for 120 days. The sand used sieved on a $2 \mathrm{~mm}$ mesh, and then treated for 36 hours with AP hydrochloric acid diluted in water in a proportion of $600 \mathrm{ml}$ of acid for every $10 \mathrm{~L}$ of water, keeping 10 blade $\mathrm{cm}$ from the acidic solution above the sand level in polyethylene buckets. After this period, the sand washed with water until it removed from the excess acid, reaching a pH of 7.0 in deionized water. During every day of conducting the experiment, feces irrigated daily with $6 \mathrm{~mm}$ of water equivalent to 6 liters of water per square meter of area, according to the local average daily rainfall in the summer-autumn period. The physical characteristics of the feces allowed the germination, because the humidity was enough so that the feces did not remain compacted. There was no damage to the germination of the evaluated seeds. After 120 days, the plants present in the plates simply counted.

\section{Animal diet}

The composition of "complete" mineral mixture used for beef cattle was as following (per kg of product): $\mathrm{Ca}=172.93$ g; $\mathrm{P}=41.8 \mathrm{~g} ; \mathrm{Na}=157.09 \mathrm{~g} ; \mathrm{Mg}=7.14 \mathrm{~g} ; \mathrm{S}=26.39 \mathrm{~g}$; $\mathrm{Fe}=$ $1598.8 \mathrm{mg} ; \mathrm{F}=418 \mathrm{mg} ; \mathrm{Co}=80 \mathrm{mg} ; \mathrm{Cu}=1250 \mathrm{mg} ; \mathrm{l}=97.6 \mathrm{mg}$; $\mathrm{Se}=37.5 \mathrm{mg} ; \mathrm{Zn}=3800 \mathrm{mg} ; \mathrm{Mn}=764.4 \mathrm{mg}$. Citric $2 \%=90 \%$. The sodium content of the mineral mixture was $15 \%$ similar to that found in white salt content for cattle (16\%).

In both experiments, the animals kept in individual pens of 5 $x 5 \mathrm{~m}$, consuming a basic diet of chopped elephant grass and concentrate in the ratio of 70:30 based on dry matter, balanced to achieve the requirement of maintenance of the animals. The offer of feed held at 09:00 and 15:00 hours. Seven days before the offering of seeds, animals confined and deprived of mineral supplementation offering. The results submitted to analysis of variance and mean test (Tukey to 5\%) for the comparison of means. All values transformed for purposes of analysis of variance in arcosenvx / 100.

Figure 1. summarizes the methodological steps of this study for proper understanding. The experimental design was completely randomized in a factorial 4 (species) $\times 3$ 
(dispersion terms) with four replications and analyzed for the presence of plants in fecal plates due to the excretion period, in which they excreted and the average number of plants in fecal plate was calculated.

\section{Conclusion}

The cattle facilitated dispersion of butterfly pea, macrotyloma and perennial soybean, but not stylosanthes. The seed husks with more resistant to digestion seedlings and more numbness remained longer in the field, surviving until suitable conditions for germination. Cattle contribute to the process of colonization of pasture because they constitute effective dispersal of the species.

\section{Acknowledgements}

The authors would like to thank UENF, FAPERJ and IFGoiano for financial support

\section{References}

Almeida JCC, Silva TO, Nepomuceno DD, Rocha NS, Araújo RP, Pereira TP, Morenz MJF, Abreu JBR (2015) Dispersão e persistência de leguminosas forrageiras tropicais após ingestão por bovinos. Biosc J. 31:867-874.

Aroeira LM, Paciullo DSC, Lopes FCF, Morenz MJF, Saliba ES, Silva JJ, Ducatti C (2005) Disponibilidade, composição bromatológica e consumo de matéria seca em pastagem consorciada de brachiaria decumbens com stylosanthes guianensis. Pesq Agrop Bras. 40:413-418.

Blackshaw RE, Rode LM (1991) Effect of ensiling and rumen digestion by cattle on weed seed viability. Weed Sci. 39:104-108.

Bråthen KM, González VT, Iversen $M$, Killengreen $S$, Ravolainen V, Ims RA, Yoccoz NG (2007) Endozoochory varies with ecological scale and context. Ecogr. 30:308320.

Bray AG, Cahill L, Paton CJ, Bahnisch L, Silcock R (1998) Can cattle spread giant rat's tail (Sporobolus pyrimidalis) seed in their faeces? In 'Proceedings 9th Australian Agronomy Conference Wagga'. (Eds DL Michalk, JE Pratley) pp. 575578. (Australian Society of Agronomy: Wagga Wagga, NSW).

Bruun HH, Poschlod $\mathrm{H}$ (2006) Why are small seeds dispersed through animal guts: large numbers or seed size per se? Oikos. 113:402-411.

Deminicis BB, Almeida JCC, Malafaia PAM, Blume MC, Abreu JBR, Vieira HD (2009) Germinação de sementes em placas fecais bovinas. Arch Zootec. 58:73-84.

Deminicis BB, Vieira HD, Almeida JCC, Araújo SAC, Guimarães Filho CC, Araújo RP, Castagnara DD, Stradiotti Júnior D (2013) Forage legume seeds submitted to in vitro and in situ fermentation techniques. Americ J Plant Sci. 4:66-70.

Doucette KM, Wittenberg KM, McCaughey WP (2001) Seed recovery and germination of reseeded species fed to cattle. J Range Manag. 54(5):575-81.

Figueroa JA, Castro SA (2002) Effects of bird ingestion on seed germination of four woody species of the temperate of Chiloe land. Plant Ecol. 160:17-23.
Gillet F, Kohler F, Vandenberghe C, Buttler A (2010) Effect of dung deposition on small-scale patch structure and seasonal vegetation dynamics in mountain pastures. Agric Ecosys Environ. 135:34-41.

Jolaosho AO, Olanite JA, Onifade OS, Oke AO (2006) Seed in the faeces of ruminant animals grazing native pastures under semi-intensive management in Nigeria. Trop Grassl. 40:79-83.

Jones RM, Noguchi M, Bunch GA (2001) Levels of germinable seed in topsoil and cattle faeces in legume-grass and nitrogen-fertilized pastures in south-east Queensland. Austral J Exp Agric. 42:953-968.

Levine JM, Murrel DJ (2003) The community-level consequences of seed dispersal plants. Ann Review Ecol Evolut Syst. 34:549-574.

Lima RV, Vieira HD, Guimarães FS, Rohem Jr NM, Silva TO, Fernandes AM, Guimarães CP, Acha AJ, Deminicis BB (2014) Germination, vigor of seeds and emergence of fabaceae seedling in bovine faeces. Am J Plant Sci. 5:21702177.

Lima RV, Vieira HD, Silva TO, Silva TO, Rocha NS, Deminicis BB (2015) Germination and vigor of fodder fabacceae seeds submitted to in vitro and in situ incubation. Am J Plant Sci. 6:2317-2328.

Lisboa CAV, Medeiros RB, Azevedo EB, Patino HO, Carlotto SB, Garcia RPA (2009) Poder germinativo de sementes de capim-annoni-2 (Eragrostis plana Ness) recuperadas em fezes de bovinos. Braz J Anim Sci. 38:405-410.

Mouissie AM, Veen CEJVD, Veen GF, Diggelen RV (2005) Ecological correlates of seeds survival after ingestion by fallow deer. Funct Ecol. 19:284-290.

Nakao EA, Cardoso VJM (2010) Recuperação e resposta germinativa de sementes de leguminosas passadas pelo trato digestório bovino. Biota Neotr. 10:189-195.

Peco B, Lopez-Merino L, Alvir M (2006) Survival and germination of mediterranean grassland species after simulated sheep ingestion: ecological correlates with seed traits. Acta Oecol. 30:269-275.

Pegado CA, Andrade LA, Félix LP, Pereira IM (2006) Efeitos da invasão biológica de algaroba - Prosopis juliflora (Sw) DC. sobre a composição e a estrutura do estrato arbustivoarbóreo da caatinga no Município de Monteiro, PB. Acta Botan Bras. 20:887-898.

Rahimi S, Mashhadi HR, Banadaky MD, Mesgaran MB (2016) Variation in weed seed fate fed to different holstein cattle groups. PLoS One. 11(4): e0154057

Silva TO, Almeida JCC, Rocha NS, Costa ZS, Lima GP, Grassi PH, Ferreira TC, Araújo RP, Abreu JBR (2007) Dispersão e germinação de leguminosas forrageiras tropicais através das fezes de bovinos. In: Congresso Internacional de Zootecnia, 9., 2007, Londrina. Anais... ZOOTEC, Londrina, 2007. CD-ROM.

Souza SO, Santana J, Shimoda A (2002) Comportamento de gramíneas forrageiras tropicais isoladas e em associação com leguminosas no Norte-Fluminense. Ciênc Agrotec. p.1554-1561. 